Vol. 10 (4): 625-632 (2020)

\title{
COMPARATIVE ANALYSIS ON THE CALCULATION METHODS OF THE MOMENT OF THE FIRST CRACK ACCORDING TO THE ALBANIAN CODES AND EUROCODES
}

\author{
Igli Kondi $^{1 *}$, Julian Kasharaj ${ }^{1}$, Erza Askushaj ${ }^{2}$, Anisa Asimi ${ }^{2}$

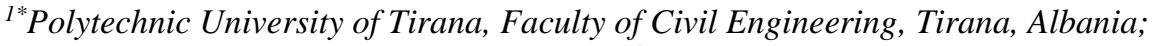 \\ ${ }^{2} K \& K$ Engineering, Tirana, Albania; \\ *Corresponding Author Igli Kondi, e-mail: i.kondi13@gmail.com; \\ jkasharaj69@yahoo.ca; erza_askushaj@hotmail.com; anisaasimi@yahoo.com
}

Received July 2020; Accepted August 2020; Published September 2020;

DOI: https://doi.org/10.31407/ijees10.407

\begin{abstract}
When Albania will be part of the European Union, Eurocodes should be used by Albanian engineers as technical codes for the structural and geotechnical design of various engineering works in the Albanian Republic. For several years now, Albanian engineers have been using Eurocodes in addition to the National codes. The main aim of this paper is to present the methodologies to determine the bending moment, which causes the first crack, based on the Albanian codes and Eurocodes. It is also aimed to highlight the differences and the similarities between the two codes, as well as the factors that affect the size of the bending moment of the first crack. Numerical examples, graphs, results, conclusions, recommendations, etc. will be shown at the end.
\end{abstract}

Keywords: bending moment of the first crack $\left(\mathrm{M}_{\mathrm{cr}}\right)$, Albanian Codes, Eurocodes, EC 2, serviceability limit state, cracks. 